\title{
A connected and plugged-in worldview: Young people and new media
}

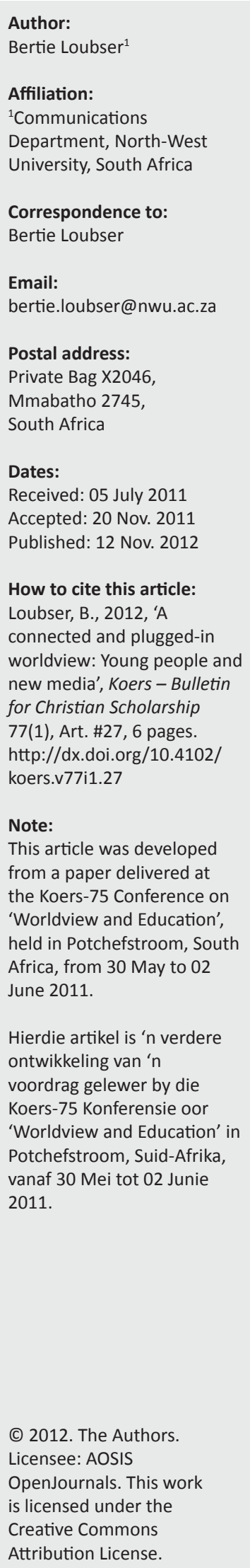

Considering their enthusiastic adoption and utilisation of the latest media technologies, the question whether today's (2011) youth is critically aware of, and paying due attention to, the multitude of influences and information that technology transmits into their lives, may legitimately be asked. Questions concerning connectivity, community interaction and peer interaction, identity (and loss of identity) and what the author terms 'space-time discrepancy' are raised in this article. The methods by which people (students or other young people) acquire and assimilate new knowledge (epistemologically), process and understand information (cognitively) and create or formulate personal meaning and significance (metaphysically), are all modified and informed by their consumption of new technologies. Therefore, in the pursuit of an 'acceptable' (by their peers and their community) worldview, young people have to grapple with both the objectively perceived, as well as the subjectively experienced manifestations of the networked world; a world 'immersed' in new media.

Opgekoppel en ingeprop - 'n Werklikheidsvisie: Die jeug en nuwe media. Gegewe die entoesiasme waarmee die jeug van vandag (2011) nuwe media-tegnologie aanvaar en gebruik, kan daar tereg gevra word of hulle enersyds bewus is van, en andersyds of dit hul werklik skeel in hoe 'n mate hierdie inligtingsoordosis hulle lewens raak. Vrae rakende interskakeling, gemeenskaps-en groepsdruk interaksie, identiteit (en identiteitsverlies), en wat die outeur as 'ruimte-tyd verwydering' beskryf, word in hierdie artikel toegelig. Die wyse waarop mense (studente of die jeug) nuwe kennis verwerf en inneem (epistemologies gesproke), inligting verwerk en verstaan (kognitief gesproke) en persoonlike waardes en betekenis verwek of formuleer (metafisies gesproke), word deurentyd verander en toegelig, synde verbruikers van nuwe tegnologie. In die jeug se soeke na 'n werklikheidsvisie wat vir hulle gemeenskap en eweknieë aanvaarbaar is, word hulle verplig om sin te maak van die objektief waarneembare, sowel as die subjektief ervaarde gewaarwording van 'n netwerk-wêreld, 'gedompel' in nuwe media.

\section{Introduction}

Whilst observing and interacting with university students on campus, the author is constantly reminded of the (almost) complete lack of 'techno-anxiety' amongst them. The adoption of new media technologies into their everyday (as well as academic) lives seems to be very much de rigueur. These young adults are truly indicative of a generation being raised in an era where 'digital media are part of the taken-for-granted social and cultural fabric of learning, play and social communication' (Ito et al. 2008:vii).

For many of the pre-digital generation (the author included), an initial apprehension towards the adoption of, and adaptation to, new technologies has given way to a recognition that 'Techno-anxiety has turned into scepticism laced with the sobering conviction that there is no turning back' (Heim 1993:74). To today's young people, who seamlessly 'integrate' into the digitally networked society, the notion of 'turning back' would probably seem like complete techno anathema [author's term]. To them it is 'inevitable', a fait accompli. We (humanity) are all inextricably bound to a digital future. The following quote by Heim (1993) clearly resonates with this 'inevitability' when he states:

We are now wedded to machines, for better or worse. The first phase of this 'marriage' was the appliance. Whether in the kitchen or on the freeway, much of our time is spent directing, tending or waiting for machines. And when all this technology becomes an interconnected system, we sit down and address the system itself; we program it. A cybernetic infrastructure coordinates instruments that measure everything from weather and traffic flow to banking transactions. We feed input into our system, which then constantly feeds information back to us. Our 'selves' plus the machines constitute a feedback loop. (p. 75)

When Danah Boyd asked teenagers why they joined MySpace on the internet, their answer was simple: 'Cuz that's where my friends are' (Boyd 2008:126). With reference to this reply, as well as to Heim's statement above, it seems that for many young people (and the following is meant 
to be ever so slightly tongue-in-cheek), being 'wedded to machines' is generally 'for [the] better', that is, positively experienced.

\section{Connected and plugged in}

Almost two decades later, Heim's feedback loop still remains an apt metaphor for the way in which young people utilise mobile phones to stay constantly connected and plugged in. Gitte Stald (2008:143) terms it '... availability - the fact that the mobile is always on, which makes users always available with no or few communication- and informationfree moments'.

\section{Hartley writes (2002):}

Connectivity is largely defined by the level of network access and interaction a person has. It is possible to be plugged in at every juncture with the advent of wearable computer technology, mobile telecommunications (mobile phones or smart phones) and internet telecommunications, which has led to $[a]$ new phase in social order, the Network Society. (p. 120)

Although the spectacular growth of mobile phone ownership amongst the young was partly a consequence of parental desire to ensure the safety (and surveillance) of their children, the possession and use of mobile phones also quickly became an important element within young people's peer culture, according to Bill Osgerby (2004:209). 'Connected' mobile phones became a key means by which young people mediated their social relationships. Possession of a suitable phone offered both a sense of independence (a factor of great import to the young), as well as access to a network of (plugged in) friendship groups. Consumer-youth, in their attempts to be always connected and plugged in, therefore seem quite willing to accept new media devices as a kind of essential prosthetic [author's observation] to their persona. The manner in which young people (students or young adults) acquire and learn new knowledge (epistemologically), process and understand information (cognitively) and create or formulate personal meaning or significance (metaphysically), are all modified and informed by their consumption of new technologies.

\section{According to Yardi (2008):}

A common notion about young people in this digital age is that they are 'a demographic of highly engaged, core members of the "always on" crowd - active users of the internet, instant messaging, video games, and social networking sites.' (p. 143)

Young people's active participation on social networking sites and their use of the technology of instant messaging (their being 'always on') leads one to ask how these technologies might influence a person's 'being'. As early as 1990 Saxby (1990) had the following to say:

New technologies are changing the way people learn, create and process information. It continues to alter the way a person views their community and their standing in the world. (p. 1)

Saxby here alludes to the direct influence new technologies may have on the formation and possibly a continued re-formation of a person's worldview. How cogent (seen in this media or technology context) the development of a young person's worldview may turn out to be, largely depends on the 'authority' each individual affords such media in their lives. The author surmises that many young people afford digital media technologies great importance in their lives. This viewpoint is supported by research done by Danah Boyd (2008:118), who relates that: 'By early 2006, many considered participation on the key social network site, MySpace, essential to being seen as cool at school.' Although she adds that this lustre has since faded somewhat, and that teens are not as infatuated with these sites as they once were, 'they continue to be an important part of teen social life'.

\section{Identity}

The astounding success of SMS (Short Message Service) or texting (an offshoot of mobile phone technology) took the media technology industry by surprise. The technology was originally conceived to be a new kind of paging system for busy professionals, but texting rapidly became a communications phenomenon. 'Youth, especially, quickly laid claim to SMS as a medium for establishing and developing peer group relationships and friendships' (Osgerby 2004:209). Besides the facts of cheapness and ease of use, the prolific use of SMS's amongst young people also posits a 'deeper' sense of connectedness between participants. In 2001 researchers at the Digital World Research Centre (DWRC) found that the exchange of text messages and the sharing of phones had evolved into a ritualised form of 'gift-giving' that worked to express and cement young people's friendships:

For young people, the rituals of exchange, mediated through phone use, are ... dependent on trust and reciprocity. The phone provides young people with a means of both demonstrating and testing out the trust that exists in their relationships. (Taylor \& Harperin in Osgerby 2004:209-210)

To many adolescents, technologies such as mobile phones are implicated in the formation of individuality and personhood (Aakhus \& Katz 2002:138). From the perspective of both an inner and outer identity, technology is increasingly used within youth culture to project a desirable image to others, to express social status and to form visible personal characteristics in the formation of an identity (Aakhus \& Katz 2002:256). To many teens, the relatively 'protected' environment of online chat rooms affords them the opportunity to be much more forthright in their conversations than would have been the case in offline, face-to-face encounters. Discussing some traits of the MySpace social networking site, Danah Boyd (2008) remarks on the 'Friends' feature:

Because Friends are displayed on an individual's profile, they [these friends] provide meaningful information about that [the profile] person; in other words, 'You are who you know.' For better or worse, people judge others based on their associations; group identities form around and are reinforced by the collective tastes and attitudes who identify with the group. (p. 130)

The implication here is that, should some of these 'Friends' be 'clever, witty or important', maybe some of those features will (by association) rub off onto the online profiler. This is perhaps a case of an uncertain or confused identity (unresolved worldview?) testing 'social waters' (so to speak) and waiting for appropriate feedback. Of course, depending on this feedback, profilers might then 'slant' their online 
personalities in such a way that respondents hold them in 'high regard'. Boyd (2008) succinctly describes this practice:

A MySpace profile can be seen as a form of digital body where individuals must write themselves into being. Through profiles, teens can express salient aspects of their identity for others to see and interpret. They construct these profiles for their friends and peers to view. While what they present may or may not resemble their offline identity, their primary audience consists of peers that they know primarily offline - people from school, church, work, sports teams, etc. Because of this direct link between offline and online identities, teens are inclined to present the side of themselves that they believe will be well received by these peers. (p. 129)

In their attempts to 'write themselves into being', these young people are not averse to 'adjusting or altering' their online constructs as many times as are deemed necessary. Buckingham (2008:8) seems to echo that particular sentiment in his comment on identity theories, when he states that 'identity [is seen] as a fluid, ongoing process, something that is permanently "under construction". From both perspectives, identity is something we do, rather than simply something we are'.

\section{Switched on?}

Up until this point, the discussion revolved around issues of everyday media usage: how young people openly embrace new technology into their social lives, how teens write themselves into being online, how the formation of an identity is permanently under construction and how one should always be on. But for all their social networking skills and general adroitness online, the question may legitimately be asked whether these young users are truly switched on, that is, critically aware of, and paying due attention to, the multitude of influences and information such technology transmits into their daily lives.

On the one hand, Tapscott (2008) portrays the digital netgeneration as:

savvy, self-reliant, analytical, articulate, creative, inquisitive, accepting of diversity, and socially conscious. Unlike their parents, who are portrayed as incompetent 'technophobes', young people are seen to possess an intuitive, spontaneous relationship with digital technology. (p. 13)

'For many kids,' Tapscott argues, 'using the new technology is as natural as breathing.'

On the other hand, Buckingham (2008) describes the digital net-generation in less favourable terms, referring to:

what one can only call the banality of much new media use. Recent studies suggest that most young people's everyday uses of the Internet are characterized not by spectacular forms of innovation and creativity, but by relatively mundane forms of communication and information retrieval. (p. 14)

Such basic mastery of computer skills, therefore, can hardly be interpreted as skills usage for critical investigation of content, that is, digitally literate and switched on. Buckingham (2008) suggests that we question:

[not] so much of how young people learn with technology, but of what they need to know about it. The need for 'digital literacy' is fast becoming a growing concern among educators and policymakers in many countries. (p. 17)

A common issue encountered by the author (in his supervision of student research) is that of 'data excess'.

Although many students are quite adroit at searching the internet for information, they seem to be rather overwhelmed by the prospect of collating and dissecting their information harvest [author's term] once it is collected. The spectre (sometimes inadvertently perpetrated, many times not) of plagiarism is of course of great concern here, although many institutions of learning are pro-actively addressing this issue. It also appears as if the content and form of the information collected presents a sizeable hurdle to students: on the internet, data is rarely presented in a 'ready to consume' student-friendly format. Schofield and Davidson (2002) elucidate further:

Information overload may be the biggest problem for younger students. Unlike library resources, the material found on the Web has not been prepared with students' level of background knowledge and reading ability in mind ... Even students with advanced reading skills sometimes found it difficult to sift through the masses of information they acquired about a topic of interest to select accurate and pertinent information. (p. 202)

The above explanation serves to reiterate what the author mentioned earlier, namely that simply having access to, and being an adept operator of technology, does not automatically translate into an ability to deal with extracted content in a critical manner. This concern is highlighted in the following statement:

Likewise, at the university level, some professors have challenged the functionalist ideas at the core of many technology-driven distance-learning initiatives. These critiques dispute the assertion that innovation (or valuable learning) is a simple consequence or function of particular technologies. (McPherson 2008:3)

But, by the same token, the author sincerely believes that we (as parents and educators) should be wary of any perceived discouragement (on the part of learners) vis-à-vis digital media and learning.

\section{Worldview and education}

It is sometimes tough for adults (parents and educators alike) to allow young people to 'have their collective heads', as it were. Ito et al. (2008) echo this sentiment:

If we look at children and youth through the lens of digital media, we have a population that has been historically subject to a high degree of systematic and institutional control in the kinds of information and social communication to which they have access. This is one reason why the alchemy between youth and digital media has been distinctive; it disrupts the existing set of power relations between adult authority and youth voice. (p. ix)

In order for the above 'alchemy between youth and digital media' to blossom, education must illustrate its support for the development and implementation of appropriate future technologies. In this quest to facilitate proper learning and understanding of the new digital literacy or knowledge base, the role of the facilitators (education) and sincere support from parents are vital. Livingstone (2008) describes it thus: 
Yet since information and communication technologies increasingly represent a key route to education, health, civic engagement, employment skills, participation in government, therapeutic advice, extended family relations, and so forth, it is here that we must ensure literacy is sufficient. Celebrating young people's enterprise and enthusiasm, while failing to support, respond, or engage with their online activities, risks failing to bring to fruition the ambitious hopes we hold not only for the internet but, more significantly, for young people. (p. 116)

One element of these 'ambitious hopes' is the expectation (on the part of parents and educators) that young people will develop the ability and insight to acquire certitude about the world they inhabit. The formation of a cogent worldview is of such import to every individual, that being prescriptive towards the young (in an adult, authoritarian way) may just preclude their healthy questioning and critical understanding of knowledge gained.

How can parents and educators then encourage young people to be critical of, or in, especially their (cherished) social engagements, without the risk of sounding authoritarian and prescriptive? Might not a departure from an overly authoritarian Christian point of view serve to engage and empower young people to unhesitatingly (and without fear of reprisal) question their engagement (entanglement?) in this world? In Marshall, Griffioen and Mouw (1983:14-25), Wolters proffers the question how Christians might legitimately use the concept of worldview. In his answer he suggests that:

To the degree that 'worldview' incorporates or suggests the concept of a comprehensive religious confession about the total scheme of things which is not theoretical or elitist in character, it is eminently suitable for Christian appropriation. (p. 24)

Thus empowered (through divine certitude) young people of faith might more readily question the existing status quo. This sense of 'freedom to question' in the search for knowledge through experience is to be encouraged. Quinn (1997) defines:

... empowerment precisely not as the provision of adult or predigested information to children nor, simply, as free access to any information, but rather as enabling children to be able to do what they can do best. (n.p.)

But this view also insists that it:

is not enough for adults to leave young people to get on with it, but rather it demands that they [adults or parents] listen, respond carefully, providing feedback on creative or other forms of activity, encouraging critical reflection, taking their participation seriously. (Livingstone 2008:116)

There are encouraging pointers that, given the opportunity, young people are able (and willing) to utilise new media constructively in order to critically engage and reflect upon issues affecting them. According to Robert Samuels (2008):

Another way of incorporating the unexpected activities of digital youth is to take advantage of the auto modern fascination with viral videos. These short digital movies can be used to collect evidence of consumer fraud and political abuse. In fact, throughout the world, young people are using new technologies to document human rights abuses and other social issues. These social activities display the possible roles new media and digital youth can play in the global democratization and social justice movements. If we still believe that teaching is meant to broaden our students' horizons, challenge them to think and behave ethically, and expose them to ideas and worlds they might not otherwise encounter, we must take seriously the ways in which new technologies address and engage them and then use their interests as a platform for ethical engagement with the world. (pp. 237-238)

Reflecting on Samuels's comment above, the author believes that in this instance, young people not only reflect on information objectively perceived, but are also willing to engage with and respond to their own subjectively experienced feelings (in a moralistic, worldview sense) regarding the documentation of human rights abuses and other social issues.

\section{Space-time discrepancy}

An unexpected corollary of the use of digital technologies is what the author terms space-time discrepancy. One effect of using digital media is that it seems to disorient users in terms of perceived time and space (place). It is almost as if time stands still for these users. Samuels (2008) describes this 'oneness' with technology thus:

Like so many other auto modern technologies, cell phones allow people to enter into a technological flow where the difference between the individual and the machine breaks down. In other terms, due to the fluid and immersive nature of these technologies, people forget that they are using them, and in many ways, they become one with their machines. (p. 234)

Because they may be so engrossed in their conversation on a cell phone, people tend to forget where they actually are, physically. This, in combination with 'time coming to a standstill', as mentioned earlier, creates what the author has termed space-time discrepancy. It seems that our pre-digital sense of (analogue) time has been displaced by notions of disrupted locale (place) and a kind of 'stunted' continuity. Samuels (2008) acknowledges this phenomenon when he comments on student behaviour he had observed:

Sometimes, I overhear the conversations these students have between classes, and these communications seem to have no other content than 'checking in' or stating the students' present location. It is as if they do not feel that they exist unless someone else hears about their current presence. Here, autonomy is shown to be dependent on the recognition of others. Furthermore, it is interesting that students often detail the location and the time of their calls as if to show that time and space are still relevant. Thus, as new auto modern technologies break with past conceptions of time and space, they also call for a continuous unconscious return to temporal and spatial coordinates. (p. 234)

Because none, or very little, of the 'curious behaviour' described above was observed in pre-digital times, one interpretation could be that digital technology removes the 
'contextualization' of perceived time and location, which in the past was 'traditionally' referenced by meeting one another at an agreed time and place. And because continuous digital time is really 'decontextualized' time, it presents only the present moment. When one chats with students about their 'infatuation' (as perceived by some pre-digitals, including the author) with cell phones, it becomes clear that many of them see very little difference between what can be regarded as 'their' own 'personal' time, and what is perceived to be a universally 'shared', 'continuous' digital time. For them (according to the author's interpretation) there seems to be no 'separate' work time (class time) and off-time (after class time), as was (is) the case for traditional pre-digitals. Except, perhaps, when sleeping, these young people are truly 'always on'. In a way, their anxiety of being 'disconnected' or 'off-air' due to a cell phone battery having gone flat is concretised by an extremely interesting analogy that Strate (1996) makes between Eternal Time and Machine Time:

There is more than a passing similarity here between the God of Abraham and the god of the machine; even with surge protectors, anyone working with computers for any length of time is aware of the uncertain temporal continuity of their microworlds. A momentary discontinuity in the flow of electricity and the computer may freeze - time stops! Thus, the computer's digital time has something in common with the theistic or sacred time. (p. 355)

The analogy might be taken a step further, whereby young people seem to regard time spent 'disconnected, offline or off-air' literally as time lost; a virtual 'gap' in the timeline/ lifeline describing their existence. Being continuously connected, plugged into the loop and present, as it were, is the preferred state. In a talk delivered to the American Association for the Advancement of Science Dana Boyd (2006) describes 'hanging out' on the MySpace forum as a popular form of socialisation, remarking that 'although adults often perceive hanging out to be wasted time, it is how young people get socialised into peer groups. Much of what is shared between youth is culture - fashion, music, media. The rest is simply presence'.

According to Boyd, features such as MySpace have become critical tools for teens to maintain 'full-time always-on intimate communities, where they keep their friends close even when they're physically separated.' This seems to tie in well with Samuels's contention that young people do not feel that they exist unless someone else hears about their current presence.

\section{Social media: Christian friendly?}

Although discussion and 'chat' among young people may include subjects such as worldviews and belief-systems, how 'Christian friendly' are the best-known and highly popular 'open' social media?

In a recent news article Jeremy Kryn (2011) claimed that 'Google and other major social media sites such as Facebook have "actively" censored Christian and conservative viewpoints'. A report conducted by the National Religious Broadcasters (NRB) and the American Center for Law and Justice examined the policies and practices of several major Internet-interactive new media communications platforms and service providers, including Apple and its iTunes App Store, Facebook and Google. On one occasion the 'world's most powerful search engine' (Google) prohibited the British Christian Church Institute from purchasing space for an advertisement about abortion. It was only after the Christian Institute sued Google that the search engine permitted the advertisement. The study also reports that Apple has twice removed applications that contained Christian content from its iTunes App Store. In both instances, Apple admitted that these applications were denied access because it considered the Christian viewpoints expressed in those applications to be 'offensive'.

Although the author realises that the findings of this particular study should not be interpreted as representative of an internet that is anti-Christian per se, it does highlight a particular 'position' as far as the internet's social media perspective is concerned.

There are many instances to be found, though, where the use of new media as an outlet and forum for religious discourse is encouraged. Susan Wolf (2011) called her internet review of a new book 'A new media Christian, the ultimate missionary?' By using such word-play, Wolf highlights the myriad opportunities presented by new media channels as vehicles for the public announcement of, and interactions on, matters religious. On ways in which the internet and other new media vehicles can be used to accommodate religious thinking and worldviews, Wolf quotes the following from the fourth chapter of the book she reviewed, Media, Technology, and Entertainment by George Barna:

We can also ask what difference it makes to the future of the world if the love of Christ and the beauty of God's truth are buried in Christian media vehicles that generally do not penetrate the mainstream of society. Having media that primarily, if not exclusively, offer Christian content is fine, and even potentially useful. But if we know that media and technology are what will drive the values, beliefs, relationships, and dreams of society, then isn't the bigger challenge to figure out how to avoid having Christian truth and values marginalized? Should we not instead learn how to pleasingly and powerfully incorporate a biblical worldview and godly leadership into the mainstream of the media universe? (n.p.)

\section{Conclusion}

Young people's enthusiastic embrace of all manner of new media technology (as articulated throughout this article) can result in ongoing (positive) narratives, whether some social media are Christian-friendly or not. The author firmly believes that it is precisely this global 'interconnectedness' of young people that affords those who hold a Christian worldview the opportunity to facilitate a shared conviction. 


\section{Acknowledgements \\ Competing interest}

The author declares that he has no financial or personal relationships which may have inappropriately influenced him in writing this article.

\section{References}

Aakhus, M. \& Katz, J.E., 2002, Perpetual contact, mobile communication: Private talk, public performance, Cambridge University Press, Cambridge, United Kingdom.

Boyd, Danah, 2006, 'Identity production in a networked culture: Why youth heart MySpace', American Association for the Advancement of Science', 19 February, St. Louis, MO, viewed 07 May 2011, from http://www.w3.org

Boyd, Danah, 2008, 'Why youth social network sites: The role of networked publics in teenage social life', in D. Buckingham (ed.), Youth, identity, and digital media, pp. 119-142, The John D. and Catherine T. MacArthur Foundation series on digital media and learning, MIT Press, Cambridge, MA.

Buckingham, D., 2008, 'Introducing identity', in D. Buckingham (ed.), Youth, identity, and digital media, pp. 1-24, The John D. and Catherine T. MacArthur Foundation series on digital media and learning, MIT Press, Cambridge, MA.

Hartley, J., 2002, Communication, cultural and media studies: The key concepts, Routledge, London.

Heim, M., 1993, The metaphysics of virtual reality, Oxford University Press, New York.

Ito, M., Davidson, C., Jenkins, H., Lee, C., Eisenberg, M. \& Weiss, J., 2008, 'Foreword' in T. McPherson (ed.), Digital youth, innovation, and the unexpected, pp. vii-ix, The John D. and Catherine T. MacArthur Foundation Series on Digital Media and Learning, MIT Press, Cambridge, MA.

Kryn, J., 2011, 'Facebook, Google, social media sites "actively" censor Christian content: Study', viewed 12 October 2011, from http://www.lifesitenews.com
Livingstone, S., 2008, 'Internet literacy: Young people's negotiation of new online opportunities', in T. McPherson (ed.), Digital youth, innovation, and the unexpected, pp. 101-122, The John D. and Catherine T. MacArthur Foundation Series on Digital Media and Learning, MIT Press, Cambridge, MA.

McPherson, T., 2008, 'A Rule Set for the Future', in T. McPherson (ed.), Digital youth, innovation, and the unexpected, pp. 1-26, The John D. and Catherine T. MacArthur Foundation Series on Digital Media and Learning, MIT Press, Cambridge, MA.

Osgerby, B., 2004, Youth media, Routledge, New York.

Quinn, V., 1997, Critical thinking in young minds, David Fulton Publishers, London.

Samuels, R., 2008, 'Auto-modernity after postmodernism: Autonomy and automation in culture, technology, and education', in T. McPherson (ed.), Digital youth, innovation, and the unexpected, pp. 219-240, The John D.' and Catherine T. MacArthur Foundation Series on Digital Media and Learning, MIT Press, Cambridge, MA.

Saxby, S., 1990, The age of information, Macmillan Press, London.

Schofield, J. \& Davidson, L., 2002, Bringing the internet to school: Lessons from an urban district, Jossey-Bass, San Francisco.

Stald, G., 2008, 'Mobile identity: Youth, identity, and mobile communication media', in D. Buckingham (ed.), Youth, identity, and digital media, pp. 143-164, The John D. and Catherine T. MacArthur Foundation series on digital media and learning, MIT Press, Cambridge, MA.

Strate, L. (ed.), 1996, Communication and cyberspace: Social interaction in an electronic environment, Hampton Press, Hampton.

Tapscott, D., 2008, 'Growing UP Digital: The Rise of the Net Generation', in D. Buckingham, Introducing Identity, The John D. and Catherine T. MacArthur Foundation series on digital media and learning, p. 13, MIT Press, Cambridge.

Wolf, S., 2011, 'A new media Christian, the ultimate missionary?', viewed 12 October 2011, from http://www.catholicwebsolutions.com

Wolters, A.M., 1983, 'On The Idea of Worldview and Its Relation to Philosophy', in P.A. Marshall, S. Griffioen, R.J. Mouw (eds.), Stained Glass, pp. 14-25, University Press of America, Lanham, MD.

Yardi, S., 2008, 'Whispers in the Classroom', in T. McPherson (ed.), Digital youth, innovation, and the unexpected, pp. 143-164, The John D. and Catherine T. MacArthur Foundation Series on Digital Media and Learning, MIT Press, Cambridge, MA. 